\title{
Accouplement: Vicissitudes of an architectural motif in classical France
}

\author{
Pedro P. Palazzo \\ University of Brasilia, Brasilia, Brazil
}

\begin{abstract}
Coupled columns in French architecture and the reaction to their use from the Renaissance up to the classical rationalism of the early twentieth century hinged on the debates regarding the relationship between structural stability and visual delight, over the backdrop of the search for a national classical tradition. This architectural motif was variously put forward under the argument of the load-bearing performance of materials, as a logical derivation of column spacing rules in the classical canon, or even as a reinterpretation of gothic bundled piers. The practical usefulness and moral suitability of iron reinforcement in the wide spans entailed by coupled columns accompanied these debates from the seventeenthcentury Louvre Colonnade up to Perret's case for the monumental use of reinforced concrete.
\end{abstract}

Keywords: 17th-20th centuries, France, Colonnade, Iron Reinforcement, Classical Architecture

\section{INTRODUCTION}

Accouplement consists in the use of paired columns, most notably in the context of a free-standing colonnade. It was described by the academician, Quatremère de Quincy (1755-1849), as a "fault" and a first step on the way to vice(1788). The coupling of classical columns was both a recurring motif in French classical architecture and a matter of controversy in structural and aesthetic theory.

Its use is attested already during the Renaissance, as in Philibert De l'Orme's (1514-70) designs for the châteaux of Anet (1543-66) and Villers-Cotterêts (after 1552). The canonical exemplar, however, and the only one notable enough for Quatremère to engage with explicitly, was the Colonnade on the east façade of the Louvre (ca. 1667-78). The controversy regarding the structural performance of coupled columns and their place in the classical canon was, indeed, sparked by this monumental screen, and lasted into the early twentieth century. Debates about proportions, historic precedent, and decoration alternated with speculations on thrust resistance, the suitability of flat arches to clear spans, and whether iron reinforcement were a legitimate architectural device.

In spite of the controversy, the use of coupled columns was widespread in French architecture during the eighteenth and nineteenth centuries, both as reminiscences of the monumentality of the Louvre and as practical solutions for articulating wide bays using the classical kit of parts. De l'Orme promoted them as part of his proposed adaptations of the Italian classical orders to the smaller, weaker blocks of French limestone. A century later, polemic raged on the status of coupled columns as tokens of an independent French classicism, reminiscent of gothic structures, and their appropriateness and performance as structural supports.

As structural science progressed, however, the terms of the discussion shifted from whether coupled columns were better than isolated ones to the technical means employed in stabilising any sort of classical composition. With technicians thus waiving their part in the debate, the nineteenth century saw a conflict between aesthetic condemnations of the grandeur associated with coupled columns and their frequent use as devices of monumental composition.

The account that follows points out a few among the most significant uses of coupled columns in the history of French architecture, concentrating on the critical writings that address the matter of accouplement in the classical tradition.

\section{COUPLED COLUMNS IN CLASSICAL ARCHITECTURE}

\subsection{Medieval and renaissance origins of coupled columns}

The repeated attempts at pinpointing the historical justification for coupled columns, as well as more recent refusals to do so, constitute in themselves an aspect of the history of French architectural theory. Several critics followed Claude Perrault (1613-88) in tracing the practice of accouplement back to the gothic building tradition of wide bays separated by pier bundles (Vitruve 1673, 76).

The comparison seems far-fetched by current historiographic standards; gothic piers and classical colonnades seem to belong to fundamentally different building cultures. However, rather than 
dismissing the comparison out of hand, one might wonder why it could even be considered in the first place - and be supported by classicist authors. Clues to this are to be found both in the compositional logic of gothic architecture itself, and in the technical strand in French classical architecture, which, as pointed out by architectural historian Jean-Marie Pérouse de Montclos (2001), built upon and remembered the achievements of gothic architects. The medievalist, Philippe Plagnieux traced the development of bundled piers to the dual intent of visually "carrying down to the ground the building frame" and of expressing "the new concern for spatial unification" $(2008,78)$.

The taste for clearly marked alternation between wide spans and strong, articulated piers, together with the technical skill set required to achieve it, had been handed down through De l'Orme and his generation. Scottish architect William Ward (1865-1924) remarked, tersely, that "the native, free naturalistic spirit, which [gothic] represented, remained potent in design. ... .while indirect Gothic influence is traceable even in the eighteenth" century (1911, 1:xxv).

The Baron von Geymüller (1835-1909), a precursor in the systematic historiography of French architecture, articulated a dual genealogy for the coupled colonnade: on the one hand, drawing from gothic tradition the principle of structural and visual alternation; on the other, appropriating the high Roman renaissance motif of the rhythmical bays, as popularised by Donato Bramante (Geymüller 1901, 2:378-86). The canonical twentieth-century authority on French classicism, Louis Hautecœur (1884-1973), picked up Geymüller's argument and credited De l'Orme with establishing rhythmical bays as a standard feature of French architecture (Hautecœur 1965, 1.2:285).

The Italian architect, Sebastiano Serlio (14751554) was among the first to explicitly single out certain architectural features as being specifically French(Serlio 1997). De l'Orme, who succeeded Serlio on several royal building projects, went further and argued French builders had to make adaptations to the classical orders and their rules due to the differences in structural performance between Italian marble and French limestone. At the same time, he put forward a natural right, of sorts, to create new, "national" orders, complete with specific rules for intercolumniation (De L'Orme 1567, fol. $\left.218 \mathrm{v}^{\circ}-219 \mathrm{r}^{\circ}{ }^{\circ}\right)$.

The earliest documented use of a coupled colonnade, at the château of Anet (Fig. 1), predated De l'Orme's work on that site (Hautecœur 1965, 1.2:237). De l'Orme is, however, singular for having developed a theory of rhythmical intercolumniations as an offshoot of his proposed French order (1567, fol. $\left.233 \mathrm{v} .^{\circ}-234 \mathrm{v}^{\circ}{ }^{\circ}\right)$. He exemplified this usage in the unfinished park chapel for the château of Villers-Cotterêts (ca. 1553). The record

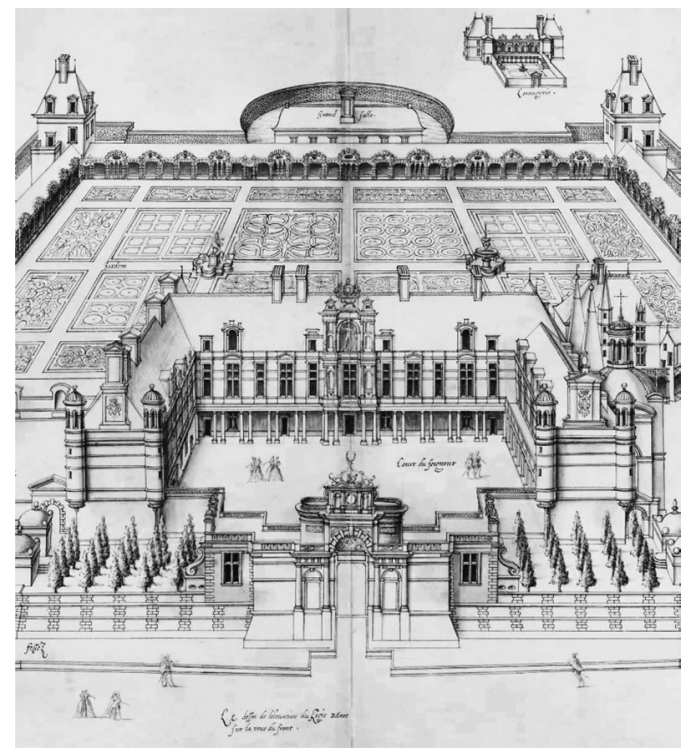

Figure 1. Front perspectival elevation view of the château of Anet. Pen and black ink with grey wash on vellum. Jacques Androuet du Cerceau, ca. 1570. British Museum 1972.U887.

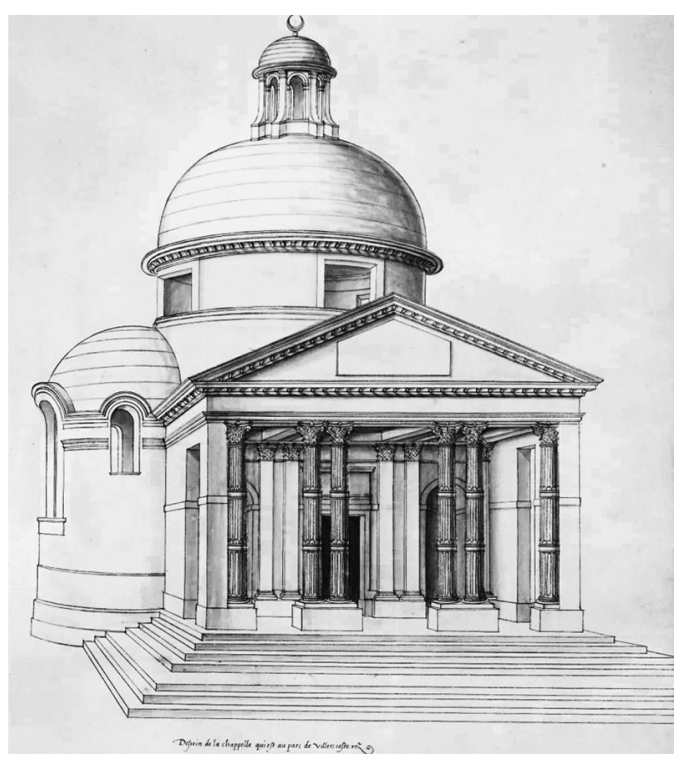

Figure 2. Front perspectival elevation view of the park chapel at the château of Villers-Cotterêts. Pen and black ink with grey wash on vellum. Jacques Androuet du Cerceau, ca. 1570. British Museum 1972.U876.

drawing, by Jacques Androuet du Cerceau (151585 ), portrays a temple front with coupled columns in the French order (Fig. 2). 


\subsection{The apex of coupled colonnades in the seventeenth century}

Bramantesque and triumphal-arch versions of the coupled column motif were common in French palaces and churches, during the late sixteenth and early seventeenth centuries (Fig. 3). A few examples displayed, in their courtyards, freestanding colonnades with coupled columns modelled after Anet, such as the hôtels of Lunaret and Manse, both in Montpellier

François Mansart (1598-1666), celebrated by art historian Claude Mignot as one of the most prolific and creative French architects in what pertains to classical ornament and structural devices (Mignot 1998, 29, 48), travelled extensively through France in his early career, picking up and reinterpreting renaissance motifs.

On the wing of the château of Blois he designed for Prince Gaston d'Orléans (1635-38), Mansart turned them into two freestanding colonnades (Fig. 4). Their construction, and particularly the groups of three columns at each end, harked back to the gothic device of pier bundles. The

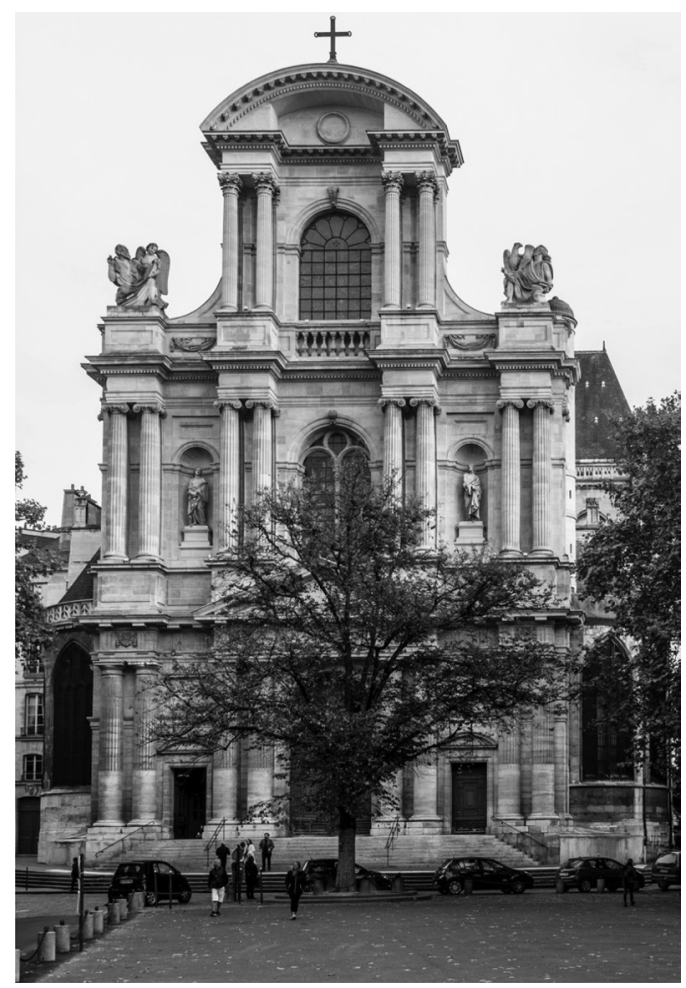

Figure 3. Salomon De Brosse (1571-1626). West façade of the parish church of Saint-Gervais, Paris, 1615-1621. Author's photograph, 2017. exceptionally wide spans, highlighted by the repetition of triglyphs on the frieze, were a tour de force made possible by the use of overhanging conical vaults, "a link between the Middle Ages and the Early Modern period" (Pérouse de Montclos 2001, 198). Such vaults were first described by De l'Orme, whose books were listed in Mansart's library (Mignot 1998, 28).

In other words, all of the structural, functional, and aesthetic reasons for the popularity of accouplement were summarised in his design for Blois: the gothic taste for wide spans and bundled piers, daylighting requirements of the French climate, and the playful display of such technical achievements as overhanging vaults and entablatures built as flat arches (Pérouse de Montclos 2001, 55).

Another three decades would elapse, however, before a coupled colonnadewas to be used on the outer façade of a building and spark, for the first time, controversy regarding its suitability as an architectural motif. These debates were to revolve, for the next three hundred years, around the new east façade of the Louvre, and for good reason. Under the influence of Cardinal Jules Mazarin (1602-61), tutor to young King Louis XIV (1643-1715), French architects and their clients showed a renewed interest in Italian style. This trend was to shape the push for grandeur in the Sun King's classicism as well as the backlash against its perceived excesses. Both aspects were nowhere more evident than in the Louvre Colonnade.

The premier architecte du roi, Louis Le Vau (1620-70), was acknowledged by art historian Hilary Ballon $(1999,104)$ as a follower of Mansart. In his designs for the enlargement of the Louvre (1657-64), Le Vau had been experimenting with dissolving the façade wall into a screen of coupled colossal, engaged columns framing expansive windows (Whiteley and Braham 1964) - an approach also explored, around 1665, by Mansart himself.

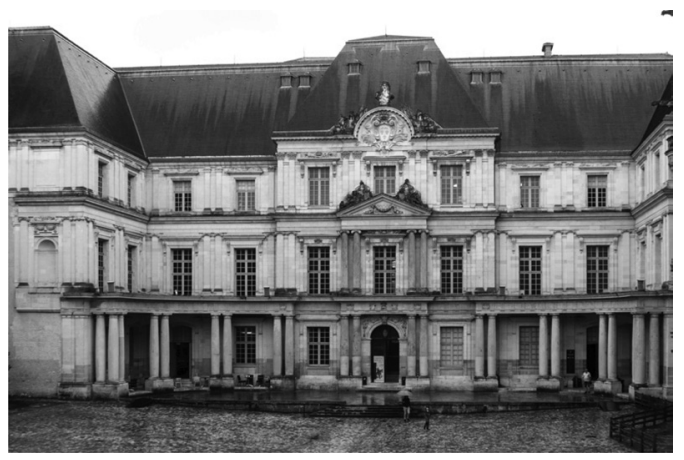

Figure 4. François Mansart, Orléans wing at the château of Blois, courtyard façade. 1635-1638. Author's photograph, 2015 (Hautecœur 1948, 2.2:205). 
Meanwhile, at the royal château of Vincennes, Le Vau introduced, in 1658, a monumental portal reminiscent of the Villers-Cotterêts chapel drawings.

After Mazarin's death, Louis XIV's superintendent of building works, financier Jean-Baptiste Colbert (1619-83) took it upon himself to micromanage the completion of the Louvre while addressing the king's political iconography. In this process, Gianlorenzo Bernini (1598-1680), the most acclaimed European architect of his time, was called upon in 1664 to provide detailed designs. These were scrapped three years later in favour of the proceedings of a committee under Colbert's close supervision. Its members were Le Vau, the royal painter, Charles Le Brun (1619-1690), and Mansart, replaced upon his death by the physician and translator of Vitruvius, Claude Perrault (Hautecœur 1924).

The committee's final design featured a colossal, freestanding colonnade of coupled columns backed by a blind wall (Fig. 5). Mansart's legacy lived on in the balance between Le Vau's "decorative approach to the orders" (Ballon 1999, 104) and Perrault's admiration for his predecessor's abstract sense of grandeur. At the same time, the completed façade exhibited, to a great ex-tent, the committee's attempt to replicate Bernini's monumentality through sheer size and repetition. It also responded to coupled colonnades within Jacques Lemercier's (1585-1654) older guichet at the opposite end of the Louvre courtyard.
The Colonnade sported exceedingly slender Corinthian columns, to compensate for the sturdiness expressed by their pairing. To span the lengths of the architraves, constructing the entablatures as flat arches - a well-established solution at the time - was not deemed sufficient: a complex system of iron tie bars, diagonal braces, and even shearresisting stirrups were put in place to ensure the stability of the system (Fig. 6). Each element, taken in isolation, was not new to French construction practice, but their combination in the Colonnade's aesthetic and structural features seemed daring and even shocking to contemporaries and later commentators.

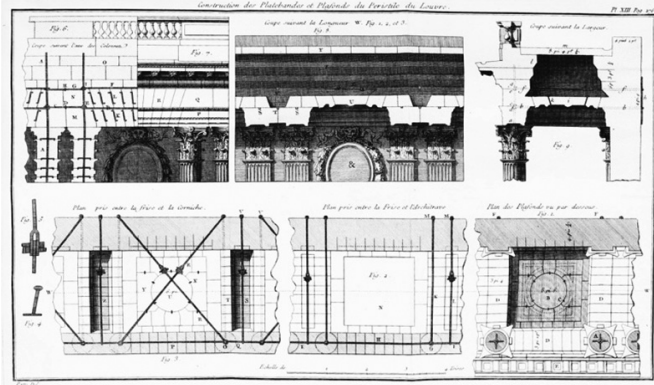

Figure 6. Iron reinforcement in the Louvre Colonnade (Patte 1769, pl. 13).

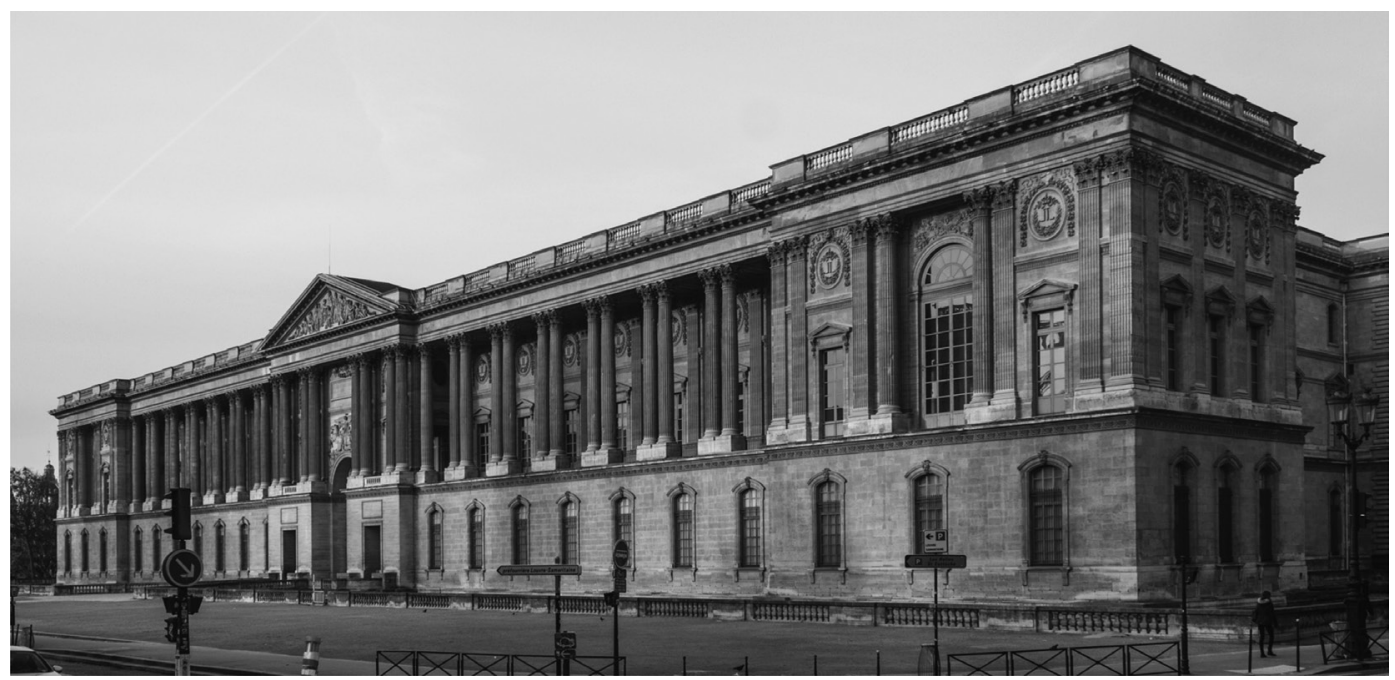

Figure 5. Louvre Colonnade (east façade). Attributed to Louis Le Vau, Claude Perrault, and François d'Orbay, 1667-78. Author's photograph, 2017. 


\section{THE COUPLED COLONNADE AS ACONTROVERSIAL MOTIF}

\subsection{Structural debates}

Claude Perrault, later to be regarded by academician Jacques-François Blondel (1705-74) as the chief, if not sole author of the Colonnade, took great pains to justify this design both after antique precedent and on the grounds of national preference. The latter he deemed "different from that of the Ancients, and perhaps in this it owes something to gothic, in that we enjoy air, daylight, and openings" (Vitruve 1673, 76). Perrault's technical justification was, on the other hand, convoluted and flimsy; it seemed to address the need to resist the outward thrust of the flat arches spanning the depth of the loggia behind the colonnade, rather than the much more conspicuous open spans along the colonnade itself. The principle of thrust resistance in stone vaults, well known since medieval times, is that a greater mass on the outside edge of a structure is required to direct the thrust vector towards the ground. However, one would be hard pressed to explain how the longitudinal thickening achieved by the coupled columns would increase resistance to transversal forces.

It was no wonder, then, that mathematician and architect François Blondel (1618-86) misunderstood Perrault's argument and made a long refutation of the usefulness of coupled columns in supporting, not the ceilings covering the depth of the colonnade, but the span of the architraves along the façade itself (Blondel 1675, 1:228-33). He went on to condemn Perrault's licentiousness in claiming authority from ancient innovations, a "reasoning that opened the door in all ages to unruliness," and especially to gothic "impertinences" (Blondel 1675, 1:235).

Moreover, Blondel interpreted the use of iron reinforcement not as a great technical achievement of the modern age, but, on the contrary, as a confession that the Louvre Colonnade was poorly designed and had to rely on crutches to compensate for its lack of solidity (Blondel 1675, 1:237).

The debate between Claude Perrault and François Blondel claimed, at least ostensibly, scientific and mathematical support, but relied, for the most part, on geometric solutions handed down from historical experience (Gerbino 2002, 51). Both authors were aware of the concurrent development of differential calculus by Newton and Leibniz (Berger 1993, 27), but it was not until Euler's and Lagrange's discussion of column buckling almost a century later that mathematics was to have any direct import for structural analysis (Gargiani 2008, 175).

Pierre Patte (1723-1814), who took over Jacques-François Blondel's teaching chair at the royal academy of architecture, was called on to assess weather damage to the Louvre Colonnade, which had been left unroofed due to funding cuts. This enabled him to address flat arch construction in light of the recent discovery of the use of wood and metal ties in ancient Roman buildings, as well as of recent French practice (Patte 1769, 265-68).

Patte's report on the Louvre Colonnade marked a sharp break with the earlier debate. He declined to pass judgment on the historical appropriateness of column coupling, concentrating instead on the distribution of loads. He began by reporting correctly the type of load each iron section resistedtraction or shear-, and ended up commending the reinforcements as resulting in a "solid and well thought-out" design (Patte 1769, 271-73).

Jacques-Germain Soufflot (1713-80) gave a different view of coupled columns at the church of Sainte-Geneviève in Paris, now the Panthéon. Rather than using linear colonnades of baroque inspiration, Soufflot sought to combine grouped columns with groin vaults, juxtaposing gothic pier bundles and Greco-Roman proportions. JeanBaptiste Rondelet (1743-1829) took over this controversial building project in 1770 , and proceeded to write down his findings in a general theory of structural design.

Rondelet, like Patte before him, refrained from passing any normative judgement on the appropriateness of iron reinforcement. This was a clear sign of the new constructive paradigm, in which the choice of structural shapes was purely an issue of design, not subject to discussion on the matter of suitability to purpose. To him, accouplement was not a matter of ideology, but just another architectural object in need of technical solution. With Rondelet ended any technical pretence of selecting architectural forms based on their intrinsic structural performance. Construction technology became concerned with providing stability to any architectural form, while the debate on the merits of coupled columns retreated into aesthetic discourse.

\subsection{Aesthetic arguments}

Patte had been active at a time when technological and mathematical advances enabled new structural forms and improvements upon old ones, yet, paradoxically, theoreticians increasingly frowned upon such technical prowess. The amateur writers who came to dominate the aesthetic debate during the second half of the eighteenth century "exhibited a wish to rid one-self from the weight of stereotomy, a need for simplicity, for truth" (Pérouse de Montclos 2001, 219).

For writers such as the Jesuit priest, MarcAntoine Laugier (1713-69), this yearning for simplicity bordered on fanaticism. Laugier lauded the 
"superb portico" of the Louvre Colonnade for its "naturalness" and "truth" (Laugier 1753, 36), without regard for the hidden reinforcement. He went on to recommend the use of coupled columns on church naves (Laugier 1753, 206), reclaiming, perhaps unwittingly, Perrault's argument that the motif derived from gothic architecture and its taste for wide bays.

Rondelet's contemporary, Quatremère de Quincy, was an acclaimed academic and the main contributor to the architecture section of Diderot's and d'Alembert's Encyclopaedia, later reworked into two iterations of architectural dictionaries published in the mid-nineteenth century. His arguments thus carried great weight among practitioners and critics alike, even after his death. Moreover, he displayed a theoretical sophistication far beyond Laugier's infatuation with freestanding columns.

Quatremère built up, through several of his Encyclopaedia articles, an argument hinging on the principle that architectural composition was bound to "specific proportions" by both the laws of nature and their direct expression in tectonic form (Quatremère de Quincy 1788, 1:111). His lengthy discussion of the physical and visual weakness of coupled columns did not reflect, however, a deep interest in the study of structure or the construction process (see Quatremère de Quincy 1820, 2:56-58).

In the end, Quatremère, speaking as a teacher of architectural design, condemned the use of coupled columns merely on grounds of the danger of inspiring aesthetic flights of fancy in students by "making exceptions degenerate into rules" (1788, 1:117). Thus, he never said a word of Ange-Jacques Gabriel's (1698-1782) monumental colonnade on the Place de la Concorde (Fig. 7), which, though using single rather than coupled columns, resorted to the very same bracing systems employed at the Louvre, and even used pointed relieving vaults.

Quatremère's attitude towards coupled columns remained hegemonic in architectural theory for the remainder of the nineteenth century, thanks,
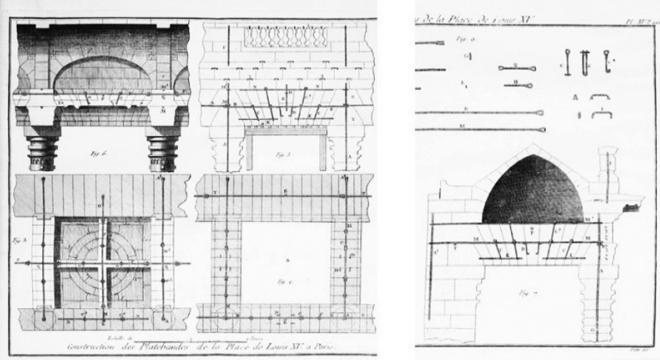

Figure 7. Iron reinforcement and relieving vault in the colonnade of the Hôtel de Crillon, Place de la Concorde (Patte 1769, pl. 14-15). in part, to the authoritative student's Dictionnaire de l'Académie des Beaux-Arts, which reproduced most of the text in the Encyclopaedia $(1858,173)$. Even authors who did not espouse Quatremère's neo-classicist views, such as the first national monuments inspector, Ludovic Vitet (1802-73), joined the condemnation of the Louvre Colonnade. To Vitet, writing in 1852 and re-edited after his death, this architectural screen was "not only a discordance in style" $(1882,135)$ with respect to his beloved, early renaissance architecture, but also a defective structure due to the need for iron bracing $(1882,140)$. François Blondel's argument remained authoritative among theoreticians at least a century after the technicians had abandoned it.

\section{COUPLED COLONNADESAND THE ARCHITECT AS TECHNICIAN}

\subsection{Criticism and the trained architect}

Another opponent of Quatremère's legacy, Eugène-Emmanuel Viollet-le-Duc (1814-79), became known for his defence of gothic construction under the argument of structural rationalism (Collins 1967, 198). Even though he defended the use of iron in combination with stone piers, he also disapproved of the Louvre Colonnade as lacking both suitability for purpose and "an art tied to our prior traditions, that is of its time, [and] perfectly French" in character (Viollet-le-Duc 1863, 1:339). In the nineteenth century, even an author who took pridein his structural reasoning had nothing to say about the technical requirements of coupled colonnades, but could only discuss its purported lack of harmony with national character.

Nevertheless, there was a truly novel point to Viollet-le-Duc's and Vitet's arguments against the Louvre Colonnade. Both the professional architect and the connoisseur politician stressed the fact that the Colonnade was the work of a physician (Viollet-le-Duc 1863, 1:374; Vitet 1882, 135). Rejecting the cultivated amateur fit well within the contemporary campaign by César Daly (1811-94) in favour of the professional organisation and recognition of formally trained architects (Épron 1997, 45-62). This corporatist attitude, equating coupled colonnades with amateurish work, was made canonical when Adolphe Lance (1813-74) replicated it in his biographical dictionary of architects $(1872,2: 197-98)$.

The professional frame of discussion, however, was to be short-lived. Even as formally trained architects claimed their unique expertise to conceive and build, their authority to assess historical architecture was being taken away by a newer professional group. In a reversal of the principle 
of unity between historical precedent and contemporary practice held dear by the École des BeauxArts (Egbert 1980, 66), early French scholars such as Louis Courajod (1841-96) claimed scientific detachment was superior to practical engagement (Talenti 2000, 237).

The German art historians, Cornelius Gurlitt (1850-1938, himself a practicing architect) and Geymüller took the lead in drawing up systematic explanations of classical architecture in France. Coupled columns were once again to become relevant objects of study, yet only at the price of no longer being critiqued in terms of their architectural merit, but rather being treated as explanatory evidence in the description of broader art historical processes.

Even as the point of discussion shifted from the aesthetic or technical aspects of coupled columns to the professional or scholarly authority of the writers, the actual use of coupled columns increased in popularity. Charles Garnier's (1825-98) winning entry for the Paris Opera (1861-75) (Fig. 8) certainly contributed to this state of affairs. It had echoes in a number of student and professional designs up to Henri Deglane's (1855-1931) Grand Palais, built for the 1900 world's fair (Hautecœur 1957, 7:465).

\subsection{Rationalist classicism}

The use of coupled columns faded together with that of load-bearing stone masonry. Ease of calculation and of laying out ever-larger, repetitive floor plates in modern buildings meant structural articulation of the sort coupled columns could provide lost favour among architects and engineers. A notable exception in this scenario were the reinforced concrete works of Auguste Perret (1874-1954) that, in a way, represented a summary of the whole French tradition of accouplement.

Among his earliest uses of this motif figures the church of Notre-Dame-de-la-Consolation in

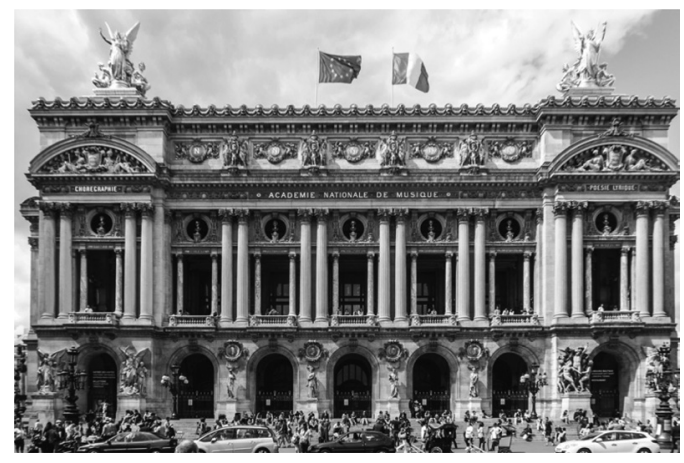

Figure 8. Paris opera house, front façade. Author's photograph, 2015.
Le Raincy, to the north of Paris (1922-23). In this building, groups of coupled concrete posts brace the four corners of the campanile, reinstating the traditional explanation that grouped columns descended from gothic bundled piers.

As free-standing colonnades made a come-back in the 1930s, several of Perret's civic buildings featured coupled columns more or less prominently. On the main entrance to his Mobilier national building (Paris, 1931), he articulated the exceptionally wide spans with two pairs of columns, thereby turning utilitarian carriageways into a monumental portico. The motif acquired baroque repetition in Perret's unbuilt competition entry for the Trocadéro palace (1933). By mirroring the Louvre Colonnade in a modern idiom, he illustrated his theory that architecture ought to give the impression of "having always been there" (Thubert 2014, 33).

To this effect, Perret's work embodied a tension between, on the one hand, the modernist intent of freeing architecture from symbolism and "any figurative feebleness whatsoever" (Abram 1997, 103), and, on the other, the evident symbolic character - and figurative by allusion to the Louvreof his colonnade.

Perret's protégé, Fernand Pouillon (1912-86), employed the rhythmical bay as an organising principle in his reconstruction of the old harbour district in Marseilles (1951-56), though with piers rather than columns. Despite these brilliant examples, the taste for rationalist monumentality, and thus for references to the classical tradition, did not survive the 1950s.

\section{CONCLUSION}

Accouplement was a widespread architectural motif in French classicism. Even though it had its roots in the Italian renaissance, only in France did coupled columns see various, long-lasting applications as well as equally long-lasting controversy. Their use in rhythmical bays and free-standing colonnades exemplified, on several occasions, the opportunity for innovation and the limits to rulebending in classicism.

The ebb and flow in the practical and theoretical popularity of coupled columns highlights changing attitudes towards monumental façades and their relationship to structural or functional requirements. At times, accouplement was put forward as an explicit idiom signalling the peculiar character and requirements of French architecture. At other times, coupled colonnades were disparaged as foreign to the French spirit and to constructive rationality.

In the midst of these debates, architects eagerly adopted and reused the coupled column motif to 
signal and increasingly standardised set of meanings: monumentality, references to the Louvre, and compositional simplicity. The combined histories of the use and debate around coupled columns gives a parallel history of French classicism, stitching seemingly unrelated episodes into a coherent story that can be told alongside other existing narratives.

\section{REFERENCES}

Abram, Joseph. 1997. 'Auguste Perret, Le Classicisme Rationnel et La Monumentalité'. In Années 30: L'architecture et Les Arts de l'espace entre Industrie et Nostalgie, edited by Jean-Louis Cohen, 96-105. Paris: Éditions du Patrimoine.

Académie des Beaux-Arts. 1858. Dictionnaire de $l$ académie des Beaux-Arts. Paris: Firmin Didot.

Ballon, Hilary. 1999. Louis Le Vau: Mazarins Collège, Colberts revenge. Princeton: Princeton Architectural Press.

Berger, Robert W. 1993. The Palace of the Sun: The Louvre of Louis XIV. University Park, Penn.: Pennsylvania State University Press.

Blondel, François. 1675. Cours d architecture Enseigné dans l Académie Royale d Architecture. Vol. 1. Paris: L. Rouilland.

Collins, Peter. 1967. Changing Ideals in Modern Architecture 1750-1950. Montréal: McGill University Press.

De l'Orme, Philibert. 1567. Architecture. Paris: F. Morel.

Egbert, Donald Drew. 1980. The Beaux-Arts Tradition in French Architecture. Princeton: Princeton University Press.

Épron, Jean-Pierre. 1997. Comprendre léclectisme. Paris: Norma.

Gargiani, Roberto. 2008. 'La résistance des colonnes: expériences sur la qualité des matériaux et calculs de la forme parfaite au cours du XVIII ${ }^{\mathrm{e}}$ siècle'. In $L a$ colonne : nouvelle histoire de la construction, edited by Roberto Gargiani, 173-191. Lausanne: Presses polytechniques et universitaires romandes.

Gerbino, Anthony. 2002. 'François Blondel: Architecture, Erudition and Early Modern Science'. Ph.D. Dissertation. New York: Columbia University.

Geymüller, Heinrich Adolf. 1901. Die Baukunst der Renaissance in Frankreich. Vol. 2. Kröner.
Hautecœur, Louis. 1924. 'L'auteur de la Colonnade du Louvre'. Gazette des Beaux-Arts IX (745):151-168.

Hautecœur, Louis. 1965. Histoire de l'architecture Classique en France. Vol. 1.2; Vol. 2.2 (1948); Vol. 7 (1957). Paris: Picard.

Lance, Adolphe. 1872. Dictionnaire des architectes français. Vol. 2. Paris : V. A. Morel.

Laugier, Marc-Antoine. 1753. Essai sur l'architecture. Paris : Duchesne.

Mignot, Claude. 1998. 'Un architecte artiste'. In François Mansart: le génie de l'architecture, edited by Jean Pierre Babelon and Claude Mignot, 23-92. Paris: Gallimard.

Patte, Pierre. 1769. Mémoires sur les objets les plus importans de l'architecture. Paris: Rozet.

Pérouse de Montclos, Jean-Marie. 2001. L architecture à la française: du milieu du $X V^{e}$ à la fin du XVIII siècle. 2nd ed. Paris: Picard.

Plagnieux, Philippe. 2008. 'Colonnes, piliers et piles composés. Évolution du support dans l'architecture médiévale en France: problèmes techniques ou formels?' In La colonne : nouvelle histoire de la construction, 73-83.

Quatremère de Quincy, Antoine Chrysosthome. 1788. Architecture. Edited by Denis Diderot and Jean le Rond d'Alembert. Vol. 1. Encyclopédie Méthodique. Paris: Panckouke.

Quatremère de Quincy, Antoine Chrysosthome. 1820. Vol. 2. Encyclopédie Méthodique. Paris: Agasse.

Serlio, Sebastiano. 1997. Serlio on Domestic Architecture. Translated by Myra Nan Rosenfeld. New York: Dover.

Talenti, Simona. 2000. L histoire de l architecture en France: émergence d une discipline. Paris: Picard.

Thubert, Emmanuel de. 2014. 'Le mobilier national'. Construction moderne hors-série (January):22-33.

Viollet-le-Duc, Eugène-Emmanuel. 1863. Entretiens sur l'architecture. Vol. 1. Paris: A. Morel.

Vitet, Ludovic. 1882. Le Louvre et le nouveau Louvre. Paris: Calmann Lévy.

Vitruve. 1673. Les dix livres d architecture de Vitruve, corrigez et traduits nouvellement en françois, avec des notes $\&$ des figures. Translated by Claude Perrault. Paris: Jean Baptiste Coignard.

Ward, William Henry. 1911. The Architecture of the Renaissance in France. Vol. 1. London: B.T. Batsford.

Whiteley, Mary, and Allan Braham. 1964. 'Louis Le Vau's Projects for the Louvre Colonnade-I'. Gazette des Beaux-Arts LXIV (1150):285-296. 